\title{
Influence of environmental factors and biogenic habitats on intertidal meiofauna
}

\author{
Francesca Ape • Gianluca Sarà • Laura Airoldi • Francesco Paolo Mancuso • \\ Simone Mirto
}

Received: 2 March 2017/Revised: 25 September 2017/ Accepted: 7 October 2017/Published online: 17 October 2017

(C) Springer International Publishing AG 2017

\begin{abstract}
This study investigated the influence of physical and chemical conditions and biotic factors on the distribution and diversity of meiofauna in intertidal zone along a geographical gradient. At 11 sites along the Italian coast, we studied the concurring role of environmental variables, trophic resources and the presence of habitat-forming species (macroalgae vs. mussels) in controlling the meiofaunal communities. The increase of water temperature combined with local thermal conditions was associated with a decrease in nematodes and copepods, with a consequent decrease in meiofaunal abundance towards the south. However, the increase in salinity, as geographical gradient decreases, and local thermal conditions favoured the settlement of a greater number of taxa,
\end{abstract}

Electronic supplementary material The online version of this article (doi:10.1007/s10750-017-3410-1) contains supplementary material, which is available to authorized users.

Handling editor: Pierluigi Viaroli

F. Ape

Institute for Coastal Marine Environment, National

Council of Research (IAMC - CNR), Via del Mare, 3,

Torretta Granitola - Fraz., 91021 Campobello di Mazara,

TP, Italy

F. Ape · G. Sarà $(\varangle)$

Dipartimento di Scienze della Terra e del Mare,

University of Palermo, Viale delle Scienze Ed. 16,

90128 Palermo, Italy

e-mail: gianluca.sara@unipa.it influencing communities' composition. The presence of macroalgae or mussels differently influenced the community structure of meiofauna on intertidal substrates and their response to environmental factors. From our results, the presence of macroalgae coverage appeared to reduce the impact of thermal stress on meiofauna and was associated with higher levels of meiofaunal diversity with respect to mussels. This work highlighted the importance of considering the interplay among biotic and abiotic factors, resulting in local combinations of environmental conditions, in order to understand the pattern of diversity and distributions of marine organisms.

Keywords Intertidal environment - Meiofauna distribution - Community composition . Environmental factors $\cdot$ Habitat-forming species 


\section{Introduction}

The distribution and the occurrence of marine organisms at the coast change mainly through large-scale spatial-related abiotic factors such as temperature, salinity gradient, seasonality and organic carbon flux (Rohde, 1992; Ingole \& Parulekar, 1998; Gaston, 2000; Yasuhara et al., 2012). At the coast, other abiotic and biotic factors, such as wave fetch, tidal amplitude, trophic resources and organisms' interactions, are critical at local level to structure marine communities (Gaston, 2000; Gartner et al., 2013; Kroeker et al., 2016). Also human disturbances, such as coastal transformation and eutrophication, and the effect caused by climate change, can act both on small and large scales, increasing the vulnerability of marine habitats (Airoldi \& Beck, 2007; Brierley \& Kingsford, 2009; Crain et al., 2009; Coll et al., 2010; Semprucci et al., 2015). Thus, to better understand the pattern of diversity and distributions of marine organisms, we need to consider this plethora of biotic and abiotic factors as interplaying among those that, acting at different scales, shape local diversity (Gaston, 2000; Menge et al., 2004; Kroeker et al., 2016). The marine intertidal zone is a perfect model to study the concurrence of different factors in shaping biodiversity; it is one of the most dynamic and challenging environments worldwide, but provides important ecosystem goods and services (Sarà et al., 2014). It represents a unique resource to explore hypotheses about patterns potentially driving organisms' distribution and diversity at different geographical scales (Hulings \& Gray, 1976; Papageorgiou et al., 2007; Covazzi-Harriague et al., 2013; Sarà et al., 2014). Fluctuations in a wide array of physical forces, like wave exposure, tide amplitude and anthropogenic disturbance, are main determinants in driving the distribution of organisms (Papageorgiou et al., 2007, Helmuth, 2008, Covazzi-Harriague et al., 2013; Sarà et al., 2014; Kroeker et al., 2016). These factors may covary, affecting the intertidal substrate, and the occurrence and the characteristics of habitat-forming species, which in turn influence (both directly and indirectly) food and shelter availability for other organisms (Gartner et al., 2013) and strengthen the effect on local diversity further. Most research in intertidal zones has focused on macro-organisms such as macro-zoobenthos and algae (e.g. Benedetti-Cecchi et al., 2001; Bulleri et al., 2002; Covazzi-Harriague \&
Albertelli, 2007; Defeo \& McLachlan, 2013), while only scant research has focused on meiofauna (Giere, 2009), paying more attention to sandy beach systems (e.g. Rodríguez et al., 2003; Kotwicki et al., 2005; Papageorgiou et al., 2007; Covazzi-Harriague et al., 2013). Meiofauna comprise the organisms that are amongst the most abundant and diverse metazoans on Earth (Balsamo et al., 2010); they play a key role in the functioning of the food webs and sustain critical ecological processes (Danovaro \& Fraschetti, 2002). They provide a suitable model for the study of marine biodiversity and biogeographic patterns of benthic marine organisms (Kotwicki et al., 2005; Danovaro et al., 2008; Curini-Galletti et al., 2012; Carugati et al., 2015), potentially providing useful information for planning monitoring and conservation strategies (Sandulli et al., 2010; Zeppilli et al., 2012; Bianchelli et al., 2013; Zeppilli et al., 2013; Semprucci et al., 2016). Distribution and diversity of meiofauna are affected by several abiotic and biotic factors acting on different spatial scales, from the main geographical-related gradients (i.e. temperature, salinity) (Hulings \& Gray, 1976; Soltwedel, 2000) to local physical-chemical variables, in particular in exposed and unstable environments, like intertidal zones (Albuquerque et al., 2007; Kotwicki et al., 2014). However, most of the studies on meiofaunal distribution did not show a clear latitudinal pattern (Kotwicki et al., 2005; Gobin \& Warwick, 2006). In addition, biotic factors, such as the presence of intertidal rocky-shore-forming species like large macroalgae and sessile macrofauna (i.e. mussel beds and oysters, coral and vermetid reefs), increase the structural complexity of substrate and concur in physically and chemically structuring the intertidal, emerging as some of the most crucial determinants in structuring meiofaunal communities (Norkko et al., 2001; Danovaro \& Fraschetti, 2002; Reise, 2002; Kostylev et al., 2005; Danovaro et al., 2007; Bianchelli et al., 2013). A lot of studies have shown the role of macroalgae in influencing meiofaunal settlement and distribution, trapping the sediment and providing detritus as useful food for grazers (Gibbons, 1988a; Arroyo et al., 2004; Urban-Malinga et al., 2008), refuges from predation and dislodgment, and ameliorating physical conditions by retaining water and offering protection from desiccation (Gibbons, 1988a, b; Danovaro \& Fraschetti, 2002; Danovaro et al., 2007; Logan et al., 2008). The studies on meiofauna associated with oyster and mussel beds 
generally suggest that it is more related to functional trait organisms, such as biodeposition (Dittmann, 1990; Reise, 2002; Norling \& Kautsky, 2007; Radziejewska et al., 2009). However, exploring how all these factors (biotic and abiotic) concur in shaping local meiofaunal community is complicated by a scale effect. Therefore, the need for substantial information still exists, to investigate their relationship and explain the pattern of distribution and diversity of intertidal meiofaunal organisms. Considering that meiofaunal communities of swash intertidal zone are mostly influenced by physical constraints of this zone (e.g. temperature variability, exposure to desiccation; Hulings \& Gray, 1976), here we tested hypotheses about factors (chemical-physical conditions and trophic resources) potentially driving meiofaunal distribution and diversity, associated with two different habitat formers (macroalgae vs. mussels), on mediterranean scale. When we are aware that without community inventories it is not possible to identify accurate diversity patterns reflecting the finest community structure, here we present a coarse taxonomic analysis as we believe that also this kind of analysis can however bring us to have that correct and useful information when assessing the effects of abiotic and biotic factors on meiofaunal taxa distribution at large spatial scale. For our purpose, we planned a large survey along the Italian coast (1) to study environmental factors affecting meiofauna and their concurring role in controlling meiofaunal distribution and community composition along a geographical gradient; (2) how the occurrence of different habitatforming species can affect the abundance and community composition of meiofauna, and (3) how the habitat formers can influence the relative control of environmental factors on meiofaunal distribution and diversity in intertidal habitats.

\section{Materials and methods}

Study area, sampling and environmental variables

Factors affecting meiofaunal distribution along a geographical gradient were studied in the Italian intertidal system by choosing 11 sites, not affected (pristine) by significant anthropogenic disturbance, which were chosen according to the proximity with areas under different levels of protection, characterised by rocky shores, spanning $9^{\circ}$ northsouth from Trieste, the northernmost site, down to Porto Palo, and $8^{\circ}$ east-west from Livorno to Otranto (Fig. 1). In 2013, from the 22nd June to 24th July, we choose three plots per site $\left(1 \mathrm{~m}^{2}\right.$ area $)$ with the same inclination and at the same height $(\sim 0.35 \mathrm{~m})$ above the mean lower low water (MLLW) level (Sarà et al., 2014), colonised by two habitat-forming species that, alternatively, were macroalgae (A) (Livorno, Orbetello, Palinuro, Taranto, Mazara del Vallo e Porto Empedocle; more than $80 \%$ of coverage) and generally characterised by the presence of Cystoseira sp., or mussels (M) (Mytilus galloprovincialis in Trieste, Ancona, Gaeta, Otranto, and/or Mytilaster minimus in Palermo; more than 50\% of coverage). Although sampling was carried out in the intertidal, where sites are wave splashed, our target in all investigated sites was the small layer (not more than $1 \mathrm{~cm}$ thick) of fine sandy sediment deposited on the rock trapped in the middle of habitat formers. We did not perform specific analysis on the sediments' grain size, but it is known that both algae and mussels trap fine sandy sediment

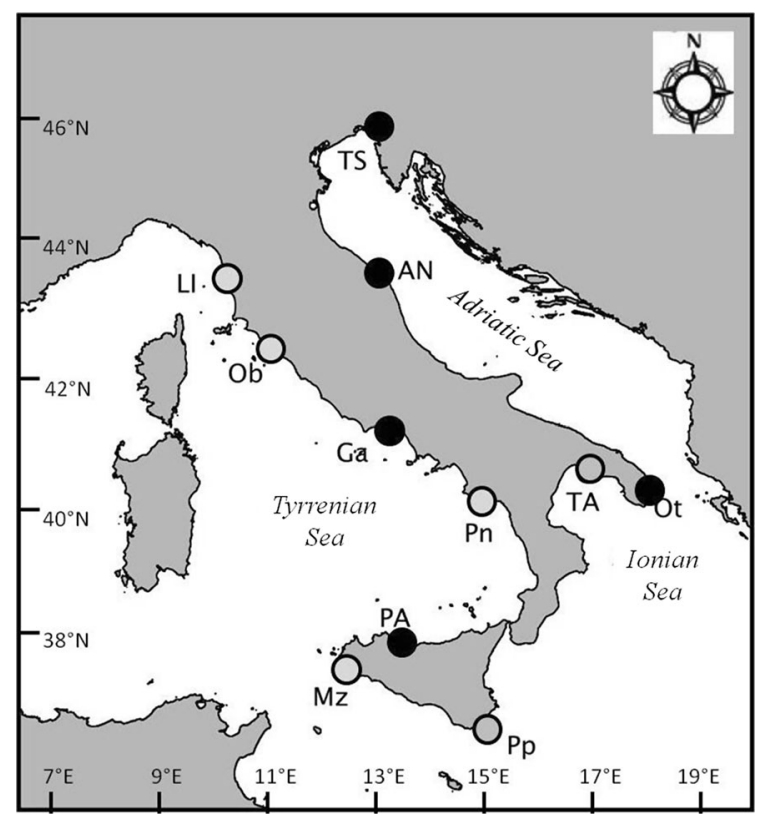

Fig. 1 Geographical position of the 11 intertidal study sites along the Italian coastline. TS Trieste, AN Ancona, $L I$ Livorno, $O b$ Orbetello, $G a$ Gaeta, $P n$ Palinuro, Ot Otranto, PA Palermo, $M z$ Mazara del vallo, $P p$ Porto Empedocle (denoting by black dots the sites with mussel (M) coverage and by grey dots the algae (A) substrate coverage). Geographic coordinates of the sites are reported in Table 1. Map projection ETRS89 
(Arroyo et al., 2004; Cole, 2010; Du et al., 2012), and accordingly we found fine-grained sediments in all investigated sites. At each site, inside each plot, we collected sediment samples to extract meiofauna, scraping the sediment by means of a paint scraper within three randomly chosen quadrats $(10 \times 10 \mathrm{~cm})$. Once collected, the sediment was fixed in $4 \%$ buffered formaldehyde in filtered $(0.4 \mu \mathrm{m})$ seawater solution until laboratory meiofauna analyses could be performed. Moreover, in the same plots, we collected three randomly chosen replicates $(\sim 10 \mathrm{~g})$ of sediment, which we stored at $-20^{\circ} \mathrm{C}$ until laboratory analyses to estimate the concentrations of phytopigments and biochemical components (proteins carbohydrates, lipids and biopolymeric carbon) (Pusceddu et al., 2003). These variables are among the most effective trophic proxies in explaining the distribution of meiofauna. Thus, our main prediction was that meiofaunal distribution and diversity were affected by both biogenic habitat and environmental factors. Then, to disentangle the roles of each component, we measured both biotic and abiotic variables along a geographical gradient. We chose the habitat former coverage and trophic resources (sedimentary phytopigments, lipids, proteins, carbohydrates and biopolymeric carbon; see below for details) as the main biotic variable, while a large number of chemical and physical factors (water temperature, salinity, body temperature, emersion and immersion time and wave fetch) were chosen as a set of abiotic variables that can be easily used as a proxy for driving factors of meiofaunal distribution and diversity.

However, meiofauna, like most ectotherms, are mainly affected by body temperature (BT) experienced during life span (from some months to a few years; Giere, 2009). Body temperature is the main effector of metabolism and, with available food, drives main life history traits (Sarà et al., 2011, 2013; Kroeker et al., 2016). Thus, to investigate whether local thermal profiles along a geographical gradient were responsible for possible diversity differences in meiofaunal community, we estimated the role of changing conditions on BT of these invertebrate ectotherms. We know that in ectotherms BT more or less mirrors the same temperature of the mean environment: (Lima et al., 1985) even more so if they live under intertidal conditions where BT results from the biophysical combinations of many factors, as shown by Helmuth (1998). While for larger organisms, such as mussels, algae or crabs, obtaining good estimates of BT is facilitated by sensors (e.g. Helmuth, 1998), in small organisms like meiofauna it is not possible to get highresolution series of BT due to their miniscule size. As a main consequence, we obtained the BT for these small organisms via a modelling approach, applying the Helmuth $(1998,1999)$ biophysical heat budget model (BE) (Kearney et al., 2010; Sarà et al., 2011, 2013). We know that many intertidal organisms live very close to their physiological limits, particularly in the intertidal zone, where they contend with both BT and food acquisition. In the intertidal, they cannot be simply estimated through rough water and air temperature and tidal range data (Helmuth, 1998), as they are not biologically relevant unless they are integrated into a $\mathrm{BE}$ to describe the climatic niche of intertidal organisms using large-scale weather and climate data archives. Such models capture the high complex interaction of factors, ultimately determining what an intertidal organism actually experiences in the field. This is achieved by deriving from the integration of aerial body temperature, submersed body temperature, desiccation and reduction in feeding time; all of these increase with increasing tidal elevation to affect the performance of intertidal organisms. The BE model was originally conceived, validated and later successfully applied to study mussel BT, and it has never been applied to study smaller organisms. Nevertheless, one of the most important assumptions of the original model was that heat budget should depend on body size and colour of target organisms. Thus, in our model, we set body size at $0.05 \mathrm{~cm}$, to be as close as possible to the size of most meiofaunal animals (from $30 \mu \mathrm{m}$ to $1 \mathrm{~mm}$; Giere, 2009). The colour in our model was left black, as originally conceived by Helmuth (1998). While we are aware that this should be tested with appropriate experimental research in future, leaving the colour black should not affect the outcome of the model, as meiofauna live partially immersed in the sediment. Thus, there should be no effect on heat exchanges. Having set the body size, we informed BE models for every ECOTRIP site with hourly data (2nd January 2010-31st December 2013) of tidal amplitude $(\mathrm{m})$, water and air temperature $\left({ }^{\circ} \mathrm{C}\right)$, wind direction $\left({ }^{\circ}\right)$ and speed $\left(\mathrm{m} \mathrm{s}^{-1}\right)$ for all sites, which were downloaded from the Italian Institute of Environmental Research (ISPRA) website (http://www.mareografico.it/). Irradiance (global sky) data $\left(W \times \mathrm{m}^{-2}\right)$, calculated on an hourly basis as an average for each month of the year 
under clear skies, were obtained from the European Joint Research Centre (http://sunbird.jrc.it/pvgis). Using a BE approach, we modelled, on an hourly basis, the aerial and aquatic body temperatures of an intertidal (mean lower low water [MLLW] $+0.35 \mathrm{~m}$ ) standard animal not larger than $0.05 \mathrm{~cm}$, at each site. The Mediterranean Sea is characterised by narrow tidal amplitude (not more than $30-50 \mathrm{~cm}$; Sarà et al., 2011,2014 ), so that the role of wave splash, which in turn is driven by wave height, can easily overwhelm the effects of the tide in driving patterns of aerial exposure (Helmuth et al., 2005). Because wave height data were not available for the sites investigated during the study period, hourly wind data from the ISPRA website were used to scale sea conditions according to the empirical Beaufort scale. We then converted Beaufort scale scores into wave heights using the following empirical formula: Beaufort $=$ cube root of wind velocity $\left(\mathrm{km} \times \mathrm{h}^{-1}\right) / 9$ (Beer, 1997), assuming open-sea conditions. A Beaufort 3 (indicating a wave height of $\sim 0.6-1.0 \mathrm{~m})$ is the sea condition at which intertidal organisms positioned at MLLW $+0.35 \mathrm{~m}$ should experience wave splash when the still tide level is approximately at mean sea level. Using this approach, we estimated, on an hourly basis, for each site (1) the mean annual BT of intertidal (MLLW $+0.35 \mathrm{~m}$ ) animals (OPTIMUM); (2) the amount of emersion (OFF) and immersion (ON) time as a proxy of feeding reduction; (3) the periods during which animals experienced $\mathrm{Tb}<5{ }^{\circ} \mathrm{C}$ (COLD) and (4) the number of exposures with $\mathrm{Tb}>35{ }^{\circ} \mathrm{C}$ (HOT, $\sim 8{ }^{\circ} \mathrm{C}$ higher than the normal maximum summer water temperature). This was an assumption in our modelling approach, as there were no data on meiofauna thermal tolerances and we therefore set our model boundaries to those of the mussels above. These measures were expressed as a percentage of exposure time (\%). Moreover, we calculated the average wave fetch using the method of Burrows et al. (2008) and reported this in $\mathrm{km}$. The values of temperature and salinity used in this study were derived from the hourly seawater temperature measured about $1 \mathrm{~m}$ below the surface, in each site, by the Italian Oceanographic Buoy Network maintained at ISPRA (http://www. mareografico.it/) and satellite-derived Sea Surface Salinity (SSS) daily data, obtained from Copernicus Marine Service Products (marine.copernicus.eu). We considered the mean of values for 3 days before the sampling day.
Trophic variables: phytopigments and biochemical variables

Total phytopigments (CPE) were estimated as the sum of chlorophyll-a and phaeopigments (Pusceddu et al., 2003) from sediments collected from each plot per site. Phytopigments were extracted $\left(12 \mathrm{~h}\right.$ at $4^{\circ} \mathrm{C}$ in the dark) using $5 \mathrm{ml}$ of $90 \%$ acetone, according to Lorenzen and Jeffrey (1980). Extracts were analysed spectrophotometrically (Shimadzu, UV spectrophotometer) to estimate chlorophyll-a and, after acidification by $200 \mu 10.1 \mathrm{~N} \mathrm{HCl}$, to estimate phaeopigment concentrations. Phytopigment concentrations were normalised to sediment dry weight $\left(60^{\circ} \mathrm{C}, 24 \mathrm{~h}\right)$ and reported as $\mu \mathrm{g} \mathrm{g}^{-1}$. Similarly, proteins (PRT), carbohydrates (CHO) and lipids (LIP), a biochemical proxy of quantity, quality and organic matter composition available to meiofauna, were collected from the same quadrats and analysed in triplicate on sediment samples using spectrophotometric methods (Pusceddu et al., 2003; Danovaro, 2010). The concentrations were expressed as bovine serum albumin, glucose and tripalmitine equivalents, respectively, and for each biochemical assay, blanks were obtained using precombusted sediments $\left(450^{\circ} \mathrm{C}\right.$ for $\left.4 \mathrm{~h}\right)$. We estimated the total biopolymeric carbon (BPC; Pusceddu et al., 2003) as the sum of CHO, PRT and LIP, previously converted into carbon equivalent by $0.40,0.49$ and $0.75 \mathrm{mg} \mathrm{C} \mathrm{mg}^{-1}$ factors, respectively. Furthermore, we used phytopigment contribution ( $\mathrm{CPE} / \mathrm{BPC} \%)$ having converted $\mathrm{CPE}$ concentration into carbon

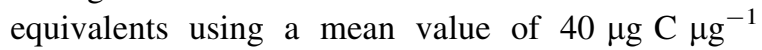
(Pusceddu et al., 2003) - and protein contribution (PRT/BPC\%) to BPC concentrations and the values of the protein-to-carbohydrate ratio (PRT:CHO) as descriptors of the ageing and nutritional quality of sediment organic matter (Pusceddu et al., 2010).

\section{Meiofauna analysis}

Meiofaunal samples were sieved through a $37-\mu \mathrm{m}$ mesh. The fraction retained on the sieve was resuspended and centrifuged three times with Ludox HS40 (diluted with water to a final density of $1.18 \mathrm{~g} \mathrm{~cm}^{-3}$; Heip et al., 1985). The material collected was preserved in 50-ml tubes with $4 \%$ buffered formalin and staining with Rose Bengal $\left(0.5 \mathrm{~g} \mathrm{l}^{-1}\right)$. Meiobenthic organisms were counted and classified at the 


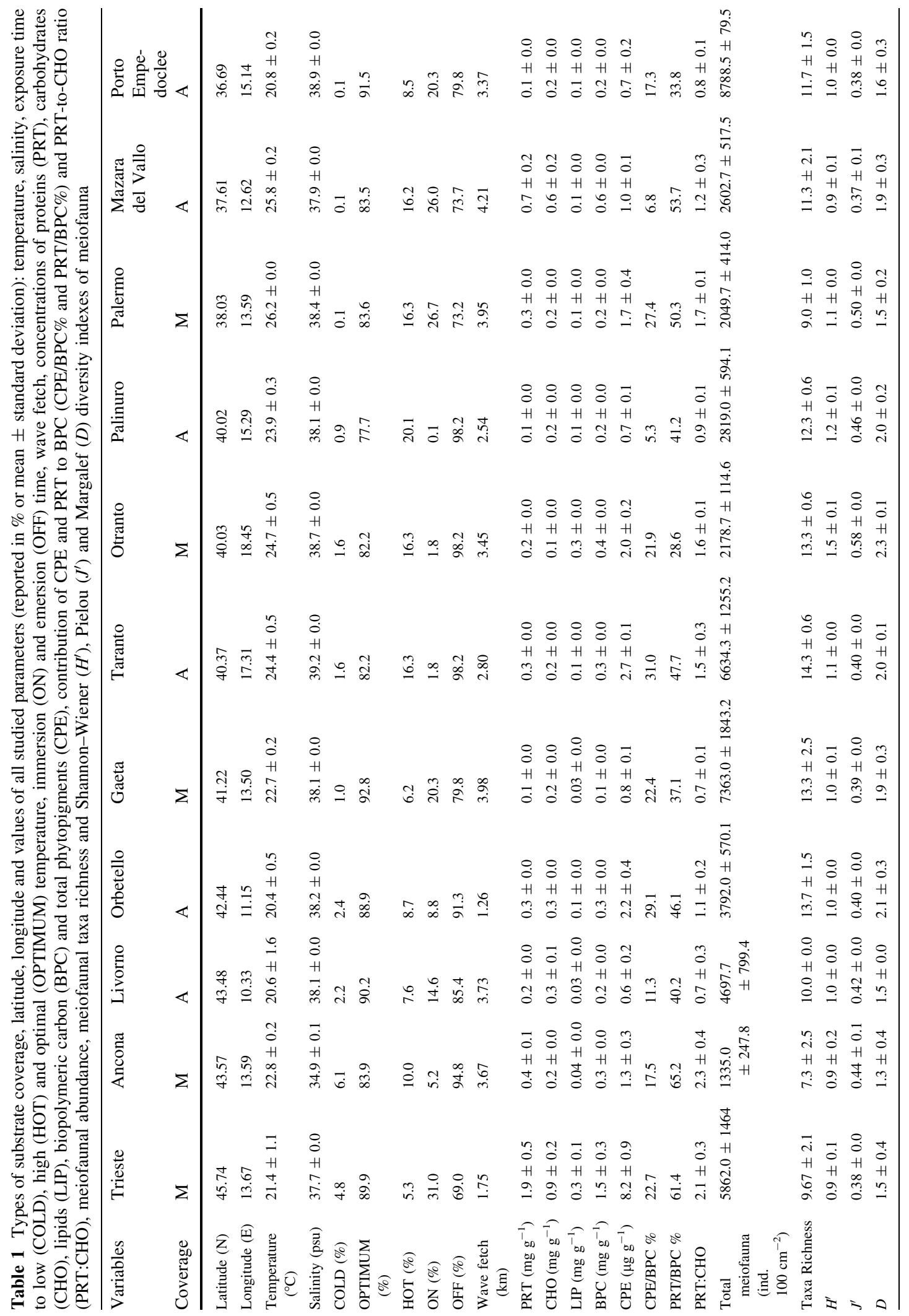


Table 2 Results of regression analysis (Statistica 6.0, StatSoft) among the principal environmental variables: latitude, longitude, temperature, salinity, exposure time to low (COLD), high (HOT) and optimal (OPTIMUM) temperature, immersion
$(\mathrm{ON})$ and emersion (OFF) time, wave fetch, concentrations of biopolymeric carbon (BPC) and total phytopigments (CPE), contribution of CPE and PRT to BPC (CPE/BPC\% and PRT/ $\mathrm{BPC} \%)$ and PRT-to-CHO ratio (PRT:CHO)

\begin{tabular}{|c|c|c|c|c|c|c|c|c|}
\hline & Latitude & Longitude & Temperature & Salinity & Cold & Optimum & \multirow[t]{2}{*}{ Hot } & \multirow[t]{2}{*}{$\mathrm{ON}$} \\
\hline Latitude & - & & & & & & & \\
\hline Longitude & n.s. & - & & & & & & \\
\hline Temperature & $-0.51 * *$ & $0.45^{* *}$ & - & & & & & \\
\hline Salinity & $-0.47 * *$ & n.s. & n.s. & - & & & & \\
\hline Cold & $0.83 * * *$ & n.s & $-0.37 *$ & $-0.73 * * *$ & - & & & \\
\hline Optimum & n.s. & $-0.47 * *$ & $-0.63 * * *$ & n.s. & n.s. & - & & \\
\hline Hot & $-0.55 * * *$ & $0.50 * *$ & $0.77 * * *$ & n.s. & $-0.39 *$ & $-0.79 * * *$ & - & \\
\hline $\mathrm{ON}$ & n.s. & $-0.40^{*}$ & n.s. & n.s. & n.s. & $0.56 * * *$ & $-0.37 *$ & - \\
\hline OFF & n.s. & $0.40 *$ & n.s. & n.s. & n.s. & $-0.43 *$ & $0.44 *$ & $-0.90 * * *$ \\
\hline Wave fetch & $-0.48 * *$ & n.s. & $0.48 * *$ & n.s. & $-0.35^{*}$ & n.s. & n.s. & n.s. \\
\hline $\mathrm{BPC}$ & $0.47 * *$ & n.s. & n.s. & n.s. & $0.43 *$ & n.s. & n.s. & $0.48 * *$ \\
\hline $\mathrm{CPE}$ & $0.57 * * *$ & n.s. & n.s. & n.s. & $0.48 * *$ & n.s. & n.s. & n.s. \\
\hline PRT/BPC\% & $0.42 *$ & n.s. & n.s. & $-0.65 * * *$ & $0.58 * * *$ & n.s. & n.s. & n.s. \\
\hline СРE/BPC\% & n.s. & n.s. & n.s. & n.s. & n.s. & n.s. & n.s. & n.s. \\
\hline \multirow[t]{2}{*}{ PRT:CHO } & $0.37 *$ & n.s. & n.s. & $-0.51 * *$ & $0.61 * * *$ & n.s. & n.s. & n.s. \\
\hline & OFF & Fetch & $\mathrm{BPC}$ & $\mathrm{CPE}$ & \multicolumn{2}{|c|}{ PRT/BPC\% } & СРE/ВРC\% & PRT:CHO \\
\hline \multicolumn{9}{|l|}{ Latitude } \\
\hline \multicolumn{9}{|l|}{ Longitude } \\
\hline \multicolumn{9}{|l|}{ Temperature } \\
\hline \multicolumn{9}{|l|}{ Salinity } \\
\hline \multicolumn{9}{|l|}{ Cold } \\
\hline \multicolumn{9}{|l|}{ Optimum } \\
\hline \multicolumn{9}{|l|}{ Hot } \\
\hline \multicolumn{9}{|l|}{$\mathrm{ON}$} \\
\hline OFF & - & & & & & & & \\
\hline Wave fetch & n.s. & - & & & & & & \\
\hline $\mathrm{BPC}$ & $-0.47 * *$ & $-0.39 *$ & - & & & & & \\
\hline $\mathrm{CPE}$ & $-0.35^{*}$ & $-0.58 * * *$ & $0.88 * * *$ & - & & & & \\
\hline PRT/BPC\% & n.s. & n.s. & $0.51 * *$ & $0.44 *$ & - & & & \\
\hline СРЕ/ВPC\% & n.s. & n.s. & n.s. & $0.38^{*}$ & n.s. & - & - & \\
\hline PRT:CHO & n.s. & n.s. & $0.52 * *$ & $0.56 * * *$ & $0.71^{\prime}$ & & h.s. & - \\
\hline
\end{tabular}

We reported the values of $R$ and $P(* * * P<0.001, * * P<0.01, * P<0.05$, n.s. not significant)

major taxa level of taxonomic discrimination using a stereomicroscope (LEICA M80) at 40× magnification. The abundance of total meiofauna and of single taxa was reported to the surface unit $(10 \times 10 \mathrm{~cm}$ area $=100 \mathrm{~cm}^{2}$ ).
Statistical analyses

The relationships between geographical gradients and all measured variables (water temperature, salinity, body temperature, emersion and immersion time, wave fetch and trophic resources), and their correlation with abundance and diversity of meiofauna, were examined through linear regressions (Statistica 6.0, StatSoft). Univariate and Multivariate Permutational 
Analysis Of Variance (PERMANOVA; Anderson, 2001; McArdle \& Anderson, 2001) was performed to test differences in biochemical components (quantity, quality and organic matter composition) and meiofauna (abundance, taxa richness, diversity indexes and community structure) between the two types of biogenic habitats (algae [A] and mussel [M]; 2 levels, fixed). PERMANOVAs were based on Euclidean distance matrices calculated on normalised data (for organic matter variables) or Bray-Curtis similarity matrices after square root transformation of the data (for meiofaunal parameters), using 9999 random permutations of the appropriate units (Anderson, 2001). Here, we expressed the diversity through taxa richness and a number of diversity indexes, such as the Margalef index $(D)$, Shannon-Wiener index $\left(H^{\prime}\right)$ and Pielou's evenness $\left(J^{\prime}\right)$, estimated by the DIVERSE routine (Clarke \& Gorley, 2006). Spatial variation of meiofaunal community structure was displayed using a non-metric multidimensional scaling plot (n-MDS), based on the Bray-Curtis similarity matrix calculated from the square-root-transformed species abundance data. SIMPER analyses were performed to assess dissimilarity in meiofaunal community between $\mathrm{A}$ and $\mathrm{M}$ substrate coverage. Because the general dominance of nematodes and copepods in the meiobenthic communities may mask the changes in the relative importance of the other meiofaunal taxa (Pusceddu et al., 2011), we also considered the community without these two dominant taxa. The analysis, based on the square-root-transformed Bray-Curtis similarity matrix with a cut-off value restricted to $60 \%$, was also performed to identify those taxa mostly contributed to the observed dissimilarity. To identify which were the principal drivers of meiofauna (abundance and community composition) in the presence of algae or mussels, we used distance-based redundancy analysis (dbRDA), based on the Bray-Curtis dissimilarities to obtain plots for each biogenic habitat (McArdle \& Anderson, 2001). We performed a draftsman plot (Clarke \& Gorley, 2006) to detect possible skewness and/or strong correlation ( $R>0.7$; see Results) among pairs of biotic and abiotic factors and we chose the following as predictor variables: temperature, salinity, OPTIMUM, OFF, fetch, BPC, PRT:CHO, CPE/BPC\%. Statistical analyses were performed using the PRIMER v6+ software (Plymouth Marine Laboratory, Clarke \& Gorley, 2006).
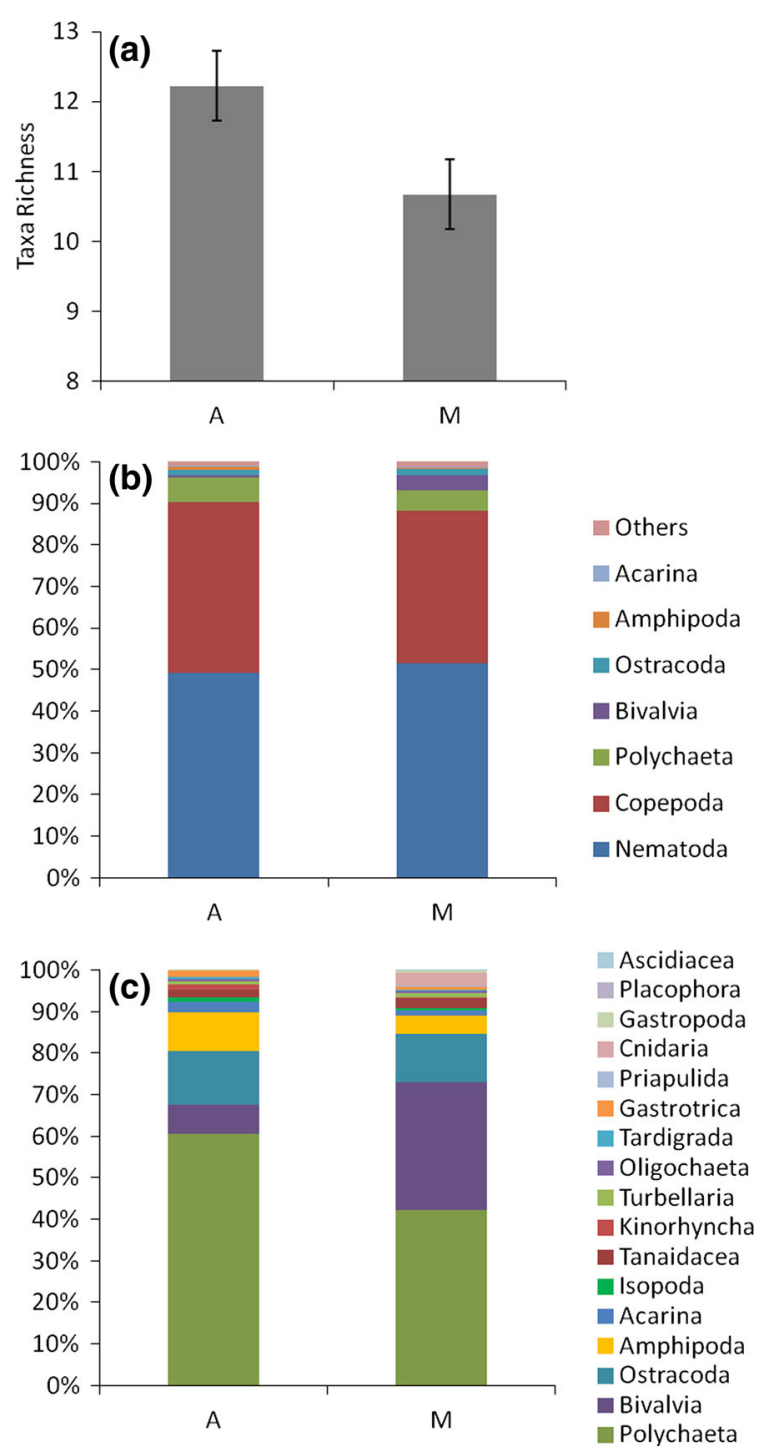

Fig. 2 Taxa richness (mean \pm SE) (a) and the composition of whole meiofaunal (b) and rare taxa (c) assemblages in the sites with macroalgae (A) and mussel (M) substrate coverage. In (b), we pooled in a single category named 'others' the taxa with percentage lower than $0.5 \%$, generally found in all sites

\section{Results}

Gradients of biotic and abiotic factors along intertidal coasts

All factors considered in this study are reported in Table 1. The regression analysis showed that environmental and trophic variables significantly varied along the geographical scale (in particular the northsouth axis) (Table 2). Water temperature increased 


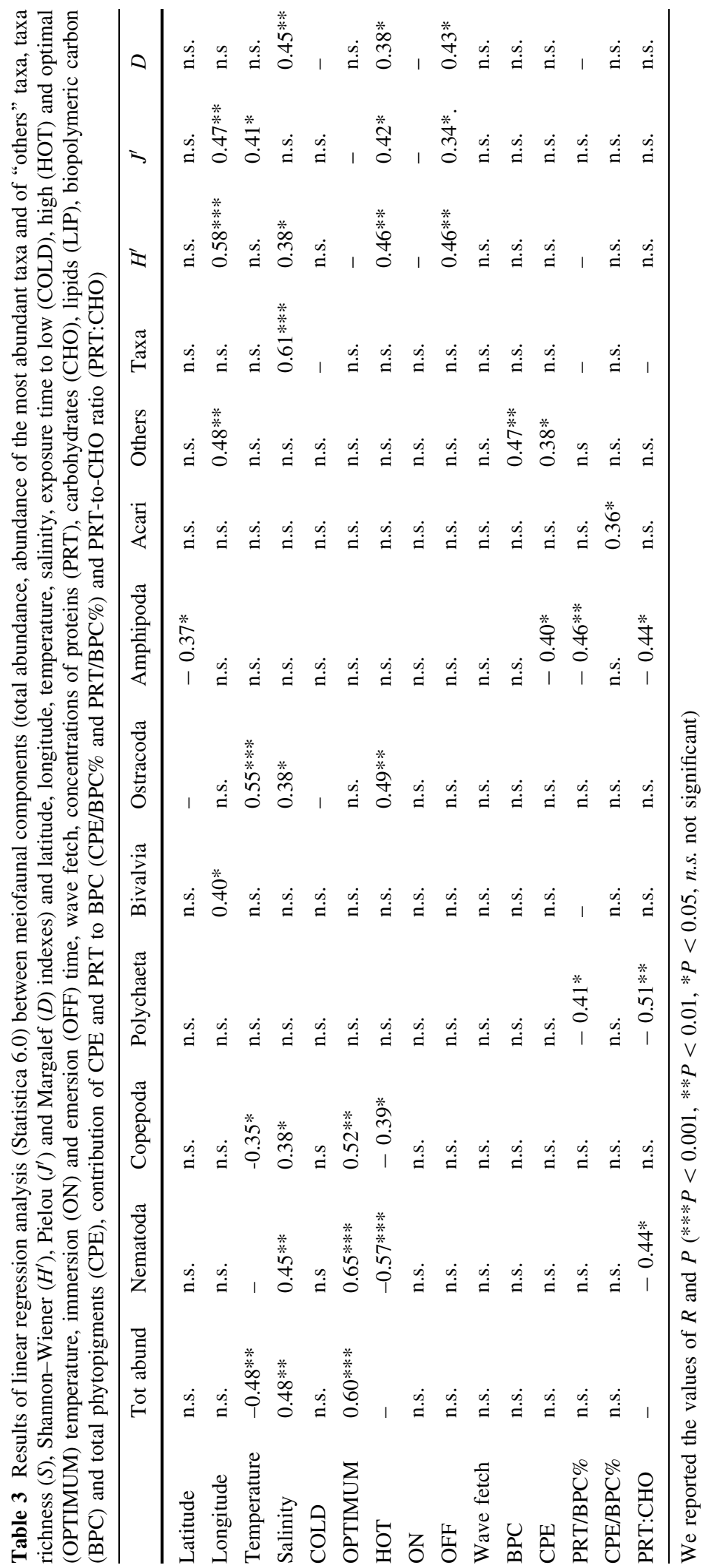


Fig. 3 Non-metric multidimensional scaling (n-MDS) plot, based on a Bray-Curtis distance matrix calculated from the squareroot-transformed, of the whole meiofaunal (a) and rare taxa (b) assemblages, between macroalgae (grey empty symbols; A) and mussel (black filled symbols; M) substrate coverage, with dissimilarity (\%) resulting from SIMPER analysis

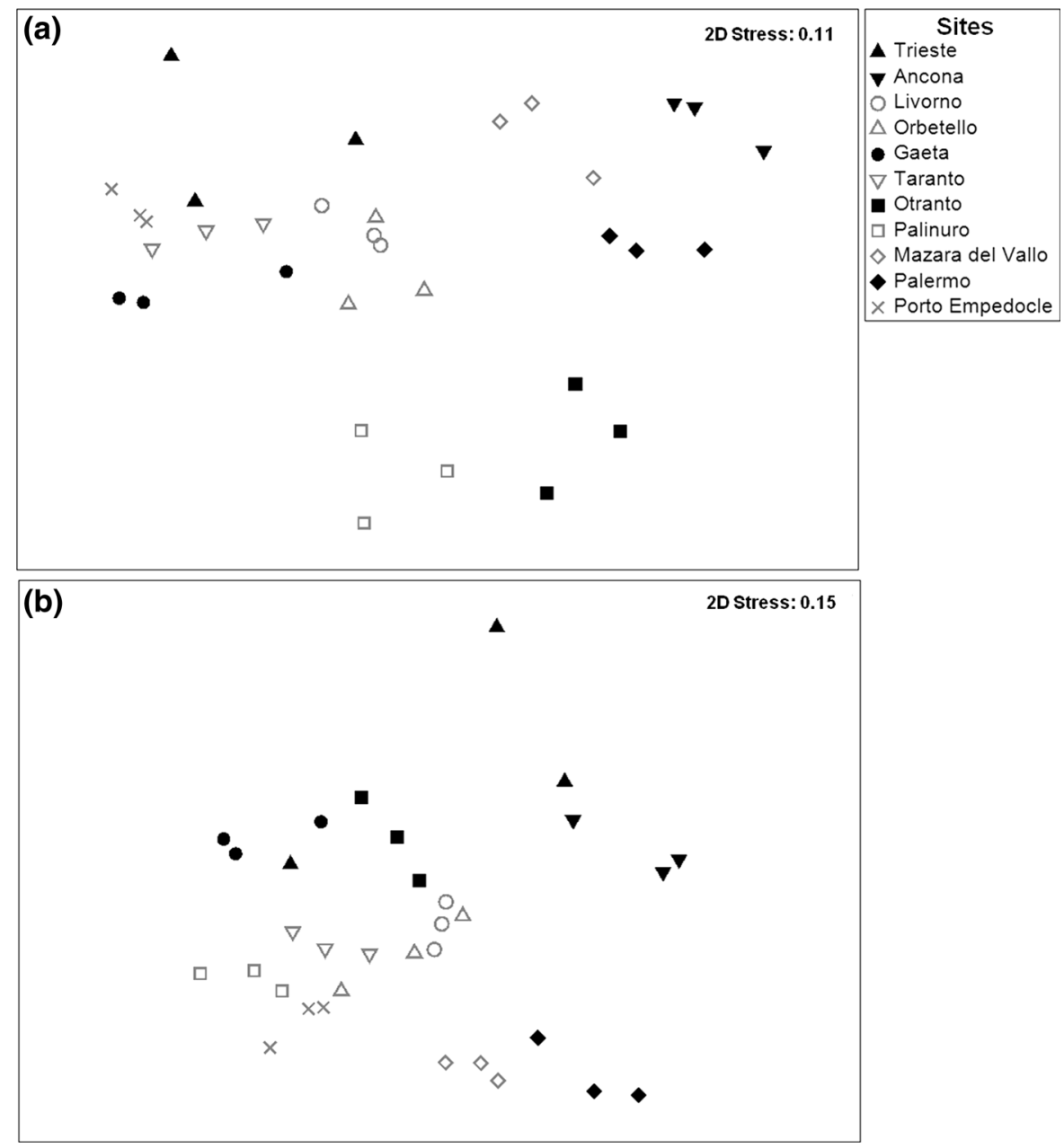

towards the south and from the west to the east $(P<0.01$; Table 2$)$, influencing positively HOT and negatively COLD and OPTIMUM $(P<0.001$, $P<0.05$ and $P<0.001$, respectively; Table 2); also, salinity and wave fetch increased from the north to the south $(P<0.01$; Table 2$)$. Emersion time (OFF) increased from the west to the east coast due to increased tidal range $(P<0.05$; Table 2$)$. Sedimentary organic matter descriptors (CPE and BPC concentrations, PRT:CHO ratio and PRT/BPC\%) showed a significant increase towards north $(P<0.05$; Table 2). CPE and BPC concentrations in the sediment displayed a correlation with local variables: positive with COLD $(P<0.05)$ and negative with wave fetch $(P<0.01)$ and OFF $(P<0.05)$. The shorter the fetch and the longer the immersion time, the higher the concentration of organic matter in intertidal habitats (Table 2). The nature of substrate cover affected both concentration and quality of trophic resources. We observed significantly higher concentration of sedimentary CPE (PERMANOVA, $P<0.05$; Online Resource 1) and significantly higher values of PRT:CHO ratio (PERMANOVA, $P<0.001$; Online Resource 1) in the sites characterised by $\mathrm{M}$ coverage than in those with A coverage, with a consequent significant difference in biochemical composition between the two biogenic habitats (PERMANOVA, $P<0.05$; Online Resource 1).

Influence of environmental variables and biogenic habitat on intertidal meiofauna

Total meiofaunal abundance ranged from $1335.0 \pm 247.8$ (Ancona) to $8788.0 \pm 79.5$ ind. $100 \mathrm{~cm}^{-2}$ (Porto Empedocle; Table 1). In all investigated sites, meiofaunal communities were dominated 

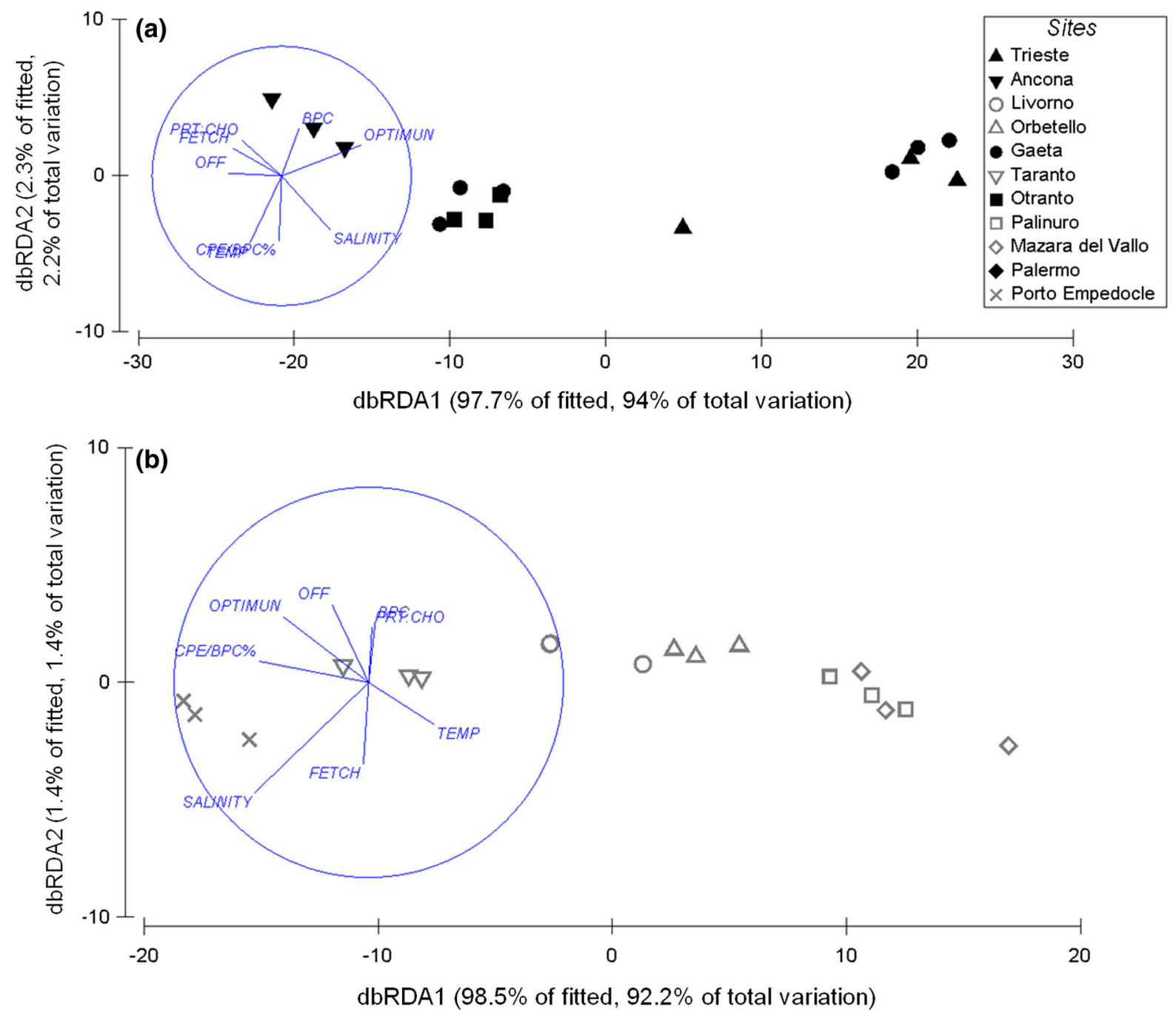

Fig. 4 Distance-based redundancy analysis (dbRDA) of (a) sites with mussel coverage (black filled symbols; M) and (b) the sites with macroalgae coverage (grey empty symbols; A) to investigate the relationships between meiofaunal abundance

by nematodes (25-61\%) and copepods (18-68\%), followed by polychaetes, bivalves, ostracods, amphipods and acarina (Fig. 2b). We pooled in a single category named 'others' the taxa with a percentage lower than $0.5 \%$, generally found in all sites (isopoda, tanaidacea, kinorhyncha, turbellaria, oligochaeta, tardigrada, gastrotricha) and more rare taxa (priapulida, cnidaria, gastropoda, placophora, ascidiacea). The results of linear regression between meiofauna and environmental variables are reported in Table 3. A significant decrease in the abundance of total meiofauna and of nematodes and copepods was detected and temperature, salinity, exposure time to thermal optimum (OPTIMUM) emersion time (OFF), wave fetch, concentrations of biopolymeric carbon (BPC), contribution of CPE to BPC (CPE/BPC\%) and PRT-to-CHO ratio (PRT:CHO)

with the increase of water temperature and HOT. Conversely, meiofaunal abundances were significantly higher in the sites with higher OPTIMUM values. The abundance and diversity (in terms of taxa richness, H' and D indexes) of meiofauna increased with salinity. All diversity indexes were also positively correlated with HOT and OFF, but negatively with OPTIMUM. Both abundance-in particular that of polychaetes-and diversity (in terms of taxa richness, H' and D indexes) of meiofauna were negatively influenced by the quality of organic matter (PRT/BPC\% and PRT:CHO). The group of "others" 
Fig. 5 Distance-based redundancy analysis (dbRDA) of (a) sites with mussel coverage (black filled symbols; M) and of (b) the sites with macroalgae coverage (grey empty symbols; A) to investigate the relationships between meiofaunal communities' composition and temperature, salinity, exposure time to thermal optimum (OPTIMUM) emersion time (OFF), wave fetch, concentrations of biopolymeric carbon (BPC), contribution of CPE to BPC (CPE/BPC\%) and PRT-toCHO ratio (PRT:CHO)
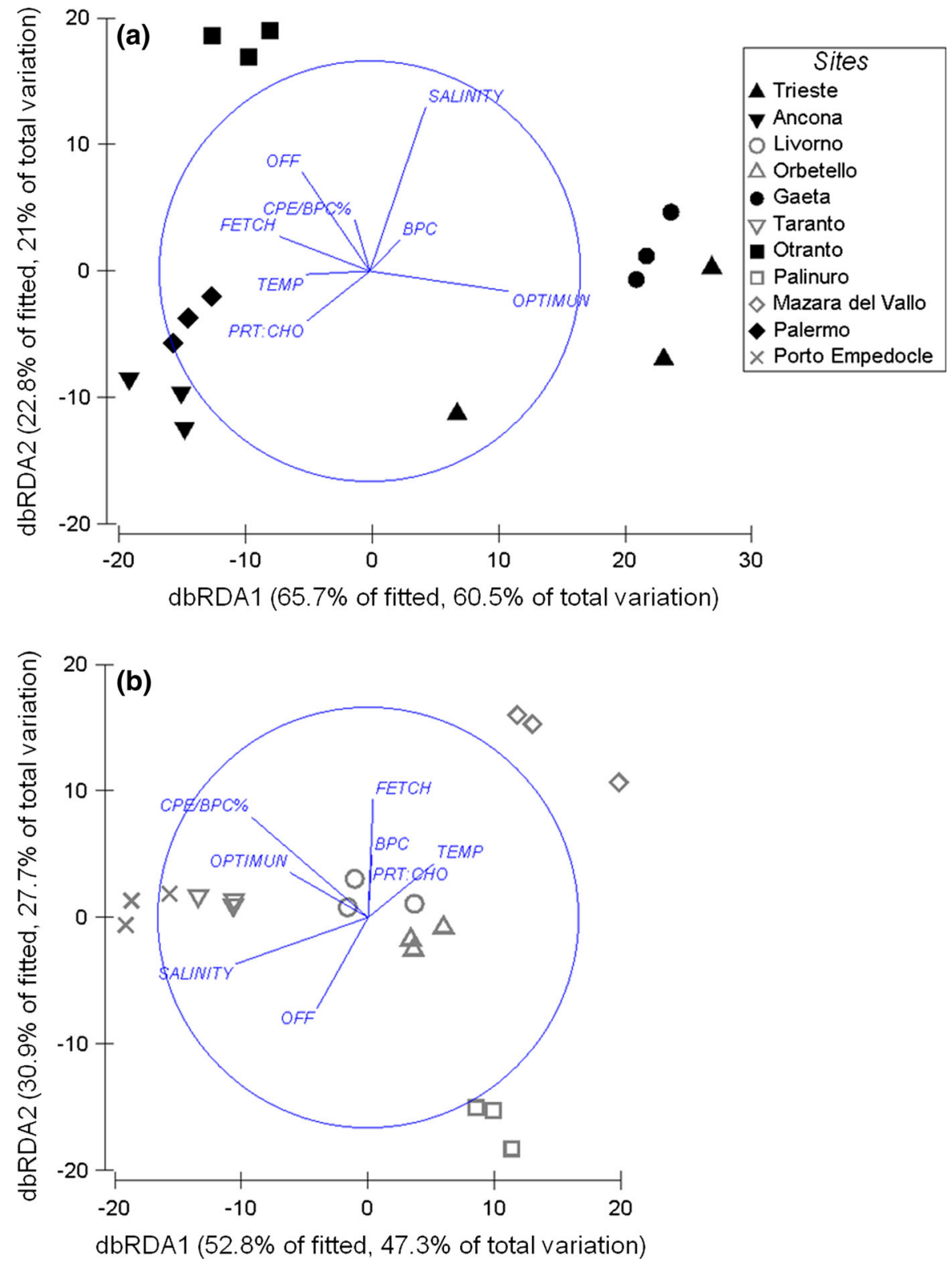

was correlated (positively) with organic matter concentration (BPC and CPE). PERMANOVA analysis $(P<0.05$; Online Resources 2$)$ showed that meiofaunal community significantly differed between habitat types (A vs. M) (Fig. 2b, c). SIMPER analyses revealed $31 \%$ of dissimilarity between $\mathrm{A}$ and $\mathrm{M}$ substrate coverage for all meiofaunal communities (MDS Fig. 3a). This difference became more evident without nematodes and copepods (dissimilarity of $49 \%$ ), and was mostly explained by polychaetes and bivalves, followed by ostracods and amphipods (MDS Fig. 3b).

Polychaetes, amphipods and ostracods were significantly higher in terms of abundance and percentage contribution to total meiofaunal abundance in the sites characterised by A coverage (PERMANOVA, $P<0.05$; Online Resources 2), where we also found significantly higher meiofaunal taxa richness (PERMANOVA, $P<0.05$; Online Resources 2), than in those with $\mathrm{M}$ coverage (Table 1; Fig. 2a-c). Conversely, meiofaunal bivalves were significantly most 

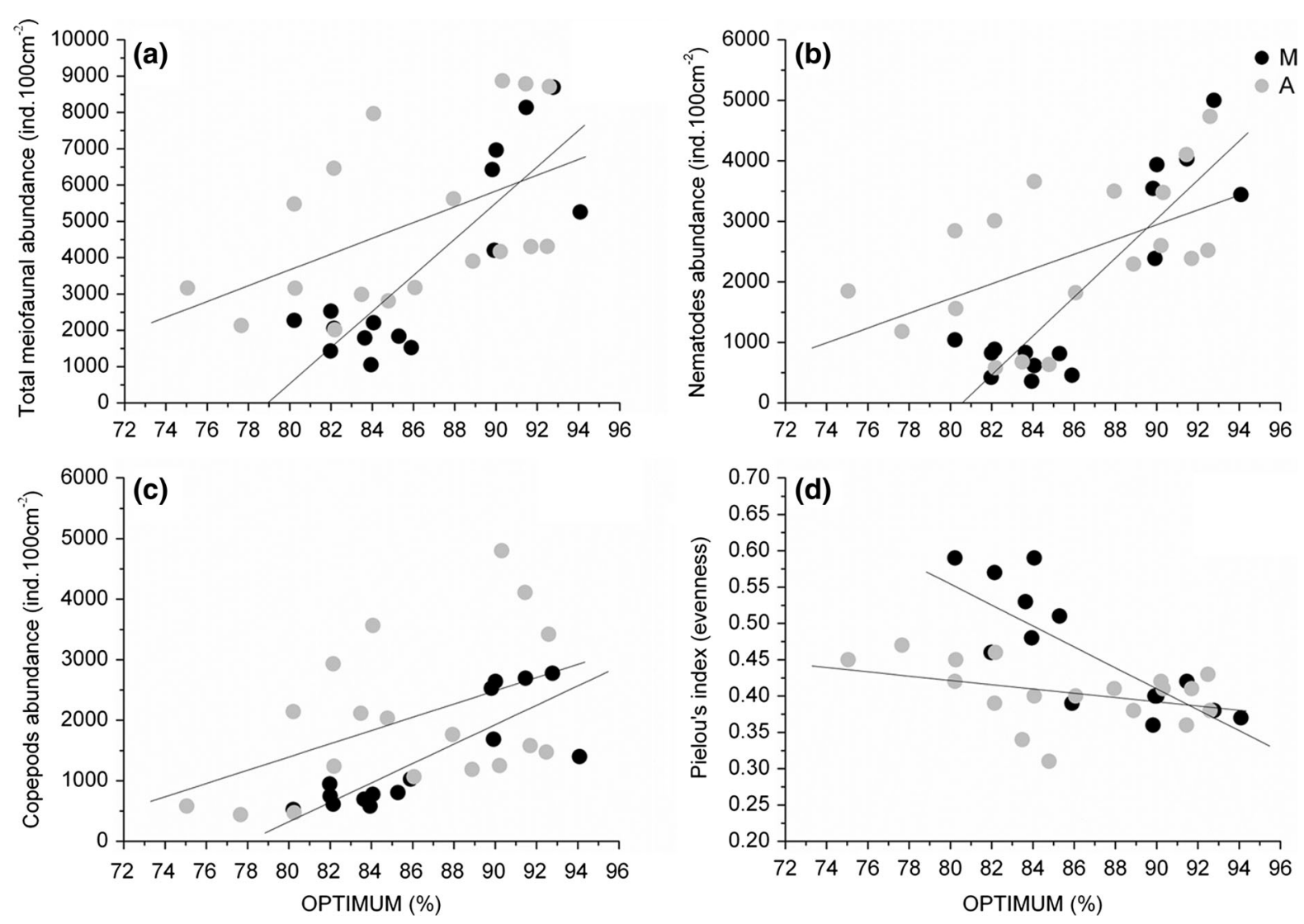

Fig. 6 Linear regressions between the values of OPTIMUM and abundance of (a) total meiofauna $(R=0.84$; $P<0.001$ in $\mathrm{M}, R=0.50 ; P<0.05$ in $\mathrm{A}),(\mathbf{b})$ nematodes $(R=0.88$; $P<0.001$ in $\mathrm{M}, R=0.54 ; P<0.05$ in $\mathrm{A})$ and (c) copepods

abundant in the sites characterised by mussels (PERMANOVA; $P<0.01$; Online resources 2). The abundance of each meiofaunal taxon was reported in Online Resources 3.

The dbRDA plot of the sites characterised by $M$ coverage (Fig. 4a) showed that the first two axes were explaining up to 97.7 and $2.3 \%$ of the variation of the fitted model, and up to 94.0 and $2.2 \%$ of the total variation in total meiofaunal abundance. As regards the community composition (Fig. 5a), the first two axes explained up to 65.7 and $22.8 \%$ of the variation of the fitted model, and up to 60.5 and $21 \%$ of the total variation. In both plots, the vectors of the drivers showed the importance of the exposure time to thermal optimum (OPTIMUM), representing the most important predictor variable, followed by emersion time (OFF) for the abundance and fetch for community. In the sites characterised by A coverage (Fig. 4b), the

( $R=0.82 ; \quad P<0.001$ in $\mathrm{M}, R=0.46 ; P=$ n.s. in $\mathrm{A}$ ), (d) Pielou's index $(R=-0.79 ; \quad P<0.001$ in $\mathrm{M}$, $R=-0.38 ; P=$ n.s. in A) in the sites with macroalgae (grey dots; A) and mussel (black dots; M) substrate coverage

first two axes of the dbRDA plot explained up to 98.5 and $1.4 \%$ of the variation of the fitted model, and up to 92.2 and $1.4 \%$ of the total variation in meiofaunal abundance. The dbRDA plot performed on community composition (Fig. 5b) showed that the first two axes were explaining up to 52.8 and $30.9 \%$ of the variation of the fitted model, and up to 47.3 and $27.7 \%$ of the total variation. In both plots, we observed that the variability among sites was based on salinity and $\mathrm{CPE} / \mathrm{BPC} \%$, representing the most important predictor variables, followed by OPTIMUM.

\section{Discussion}

Here, we investigated the role of abiotic and biotic factors on the distribution and diversity of intertidal meiofauna along the Italian coast. What emerges from 
this study (although not specifically tested) is that the tangle of biotic and abiotic factors, rather than a single main driver, affected the distribution and diversity of intertidal meiofauna, for example at southern sites higher water temperature, combined with local thermal conditions (i.e. exposure time to temperatures higher than their thermal OPTIMUM), reducing the abundance of nematodes and copepods and consequently of total meiofaunal abundance. Higher salinity values in southern sites while interacting with sitespecific factors, such as emersion time and thermal conditions, favoured the presence of a more diversified intertidal meiofaunal community. However, the presence of different habitat-forming species (macroalgae vs. mussels) differently influenced the community structure of meiofauna on intertidal substrate and their response to environmental factors, concurring with environmental variables to affect the distribution and diversity of meiofaunal organisms along the intertidal Italian coast.

Intertidal zones have been considered to be physically stressful environments, where meiofaunal communities are subjected to a complex array of environmental factors (Hulings \& Gray, 1976; Kotwicki et al., 2005; Albuquerque et al., 2007; CovazziHarriague et al., 2013; Kotwicki et al., 2014). Temperature can affect the distribution of meiofauna either directly, e.g. in exposed rocky shores, where extreme thermal conditions and desiccation rate can affect the community structure (Hulings \& Gray, 1976)) or, indirectly, promoting biological interactions such as predation and competition (Coull, 1999; Du et al., 2012). Nevertheless, our results showed that the higher water temperature in the southern Italian sites and the associated local thermal conditions, in particular the decrease in exposure time to thermal OPTIMUM of meiofaunal organisms and increase in exposure time to HOT, appeared to cause a reduction in the abundance of total meiofauna and in the dominant taxa, nematodes and copepods (Fig. 6). In fact, Wieser and Shiemer (1977) affirm that the distribution of meiofauna, in particular of some nematode species, in subtropical beach was not determined by temperatures at a given time but by the maximum temperature experienced in their habitats. Salinity was another significant factor affecting our meiofaunal organisms. Accordingly, the increase in salinity, towards the south, showed a positive correlation with abundance and diversity (in terms of taxa richness, $H^{\prime}$ and
$D$ indexes) of meiofauna, confirming the results of other studies (Chatterji et al., 1995; Ingole \& Parulekar, 1998). The relationship between longitude-related factors, higher emersion time (OFF) and higher exposure time to HOT temperature (lower OPTIMUM) appeared to cause the major increase in meiofaunal diversity. This could be explained by the capacity of some meiofaunal taxa to endure a lack of water and high temperatures reducing their metabolism (i.e. tardigrades; De Zio \& Grimaldi, 1966), or it could be due to their terrestrial origin (i.e. oligochaetes and some nematode orders; Jansson, 1968; Gheskiere et al., 2005). Local thermal conditions influenced the community evenness $\left(J^{\prime}\right)$ especially, which showed higher values in sites where the meiofaunal organisms were exposed to lower thermal OPTIMUM (Fig. 6). This suggests the presence, in these sites, of communities with higher equitability of distribution, caused by the decrease of dominant taxa (nematodes and copepods) abundance as OPTIMUM decreases. Although data on higher taxa could not reflect the biodiversity patterns at species level, our findings can help better understand the influence of abiotic and biotic factors on meiofaunal taxa distribution at large spatial scale. Trophic resources also represent important factors in controlling meiofaunal communities (Soltwedel, 2000; Giere, 2009). We observed that trophic resources were influenced by wave energy and tidal amplitude: the higher the emersion time and wave fetch, the lower the concentration of sedimentary organic matter, probably due to a reduction in the amount of deposited organic matter (Semprucci et al 2011; Covazzi-Harriague et al., 2013).

However, the physical action is entangled with the exertion of fine sediment and organic matter trapping by habitat formers (both macroalgae and mussels; Arroyo et al., 2004; Cole, 2010; Du et al., 2012). In fact, biogenic habitat plays a key role in structuring the meiofaunal communities through provision of shelter and food (Gibbons, 1988a,b; Danovaro \& Fraschetti, 2002; Arroyo et al., 2004; Danovaro et al., 2007; Logan et al., 2008; Urban-Malinga et al., 2008). While there are a few studies discussing the facilitation role of mussels on meiofauna-and most of the focus is on biodeposition effects, with sometime contrasting results - the general outcome is that organic matter emitted into mussel beds increases meiofaunal abundances (Norling \& Kautsky, 2008). Some of our descriptors of quality and quantity confirmed this 
pattern: higher concentrations of $\mathrm{CPE}$ and PRT:CHO ratio in the sediment organic matter in the sites characterised by the presence of mussels more than in those with algae coverage. Despite the importance of quantity and quality of organic matter for meiofaunal organisms (Soltwedel, 2000; Pusceddu et al., 2011), some taxa (e.g. polychaetes) were more abundant when associated with algae, where the protein contribution was lower than in the substrates colonised by mussels. As a main consequence, our results lead us to hypothesise that the structural function of substrate coverage could be more important than its trophic rule. In fact, we found higher meiofaunal taxa richness associated with the presence of macroalgae. We also observed that differences in community compositions, tested between the two types of substrate coverage (algae and mussels), became more evident when we excluded dominant taxa (nematodes and copepods, Pusceddu et al., 2011). These differences were mostly explained by the abundance of polychaetes, amphipods, ostracods and bivalves. Habitat features could play a key role in the supply and settlement of the temporary meiofaunal taxa (Bianchelli et al., 2010); in fact some rare taxa, frequently encountered as temporary meiofauna, appeared to prefer a substrate colonised by algae (e.g. polychaeta, amphipoda, isopoda) and instead other taxa preferred the presence of mussels (e.g. bivalvia, priapulida, oligochaeta, gastropoda, cnidaria and ascidiacea). The higher abundance of crustaceans taxa (in particular ostracods and amphipods) associated with the presence of algae could be due to their biological cycle being closely related to macroalgae, which in turn offers them nutrition and refuge from predation (Danovaro \& Fraschetti, 2002; Frame et al., 2007; Logan et al., 2008).

Macroalgae, in particular canopy algae such as Cystoseira sp., can reduce the impact of physical and biological factors, maintaining high levels of diversity in rocky shore habitats (Gibbons, 1988b; BenedettiCecchi et al., 2001; Crowe et al., 2013). Consistent with this, our results showed that the influence of thermal conditions (i.e. exposure time to thermal OPTIMUM) on the distribution of nematodes and copepods and, consequently, of total meiofauna and community composition, was lower in the sites characterised by the presence of macroalgae than in those with mussels (Figs. 5, 6). This could be the result of macroalgae's greater capacity to protect meiofaunal organisms from thermal stress with regard to mussels. The exposure time to thermal OPTIMUM negatively influenced the community evenness $\left(J^{\prime}\right)$, significantly only in the presence of mussels, that was probably caused by the higher abundance and dominance of nematode and copepods associated with this biogenic substrate coverage at higher values of OPTIMUM (as previously explained) (Fig. 6).

\section{Conclusions}

In conclusion, our results highlighted that the interplay among environmental factors and habitat-forming species results in sites with peculiar combinations of environmental conditions. This supported the current trend that the study of factors affecting the distribution of organisms needs to be tailored to the organism and recipient habitat, based on prior assessment of the relationship between drivers acting on multi-scales. While the main outcome of this study was based on a coarse level of taxonomic identification and we are aware that more details are needed, it can help in a context of conservation and could allow a better understanding of the mechanisms of recruitment of specific taxa in different habitats. Conservation measures could be tailored at local scale in order, for example, to preserve habitat-forming species (i.e. macroalgae), which act as ecological facilitators in harsh and stressful habitats such as the intertidal via their role as complexity and heterogeneity effectors. Indeed, they may be able to promote higher meiofaunal diversity, with important cascading effects on higher trophic levels. However, further studies are required to investigate the drivers of distribution and biodiversity of meiofauna that more carefully consider biotic interactions (i.e. predation) and anthropogenic impact and examine diversity in species and trophic roles of communities.

Acknowledgements This study was supported by the Italian project TETRIS (Observing, modelling and TEsting synergies and TRade-offs for the adaptive management of multiple Impacts in coastal Systems). We thank Dr. Alessandro Rinaldi and Dr. Chiara Giommi for support during field sampling and Anna Lossman for the fine-tuning of the English. 


\section{References}

Airoldi, L. \& M. W. Beck, 2007. Loss, status and trends for coastal marine habitats of Europe. Oceanography and Marine Biology 45: 345-405.

Albuquerque, E. F., A. P. B. Pinto, A. D. Q. Perezn \& V. G. Veloso, 2007. Spatial and temporal changes in interstitial meiofauna on a sandy ocean beach of South America. Brazilian Journal of Oceanography 55(2): 121-131.

Anderson, M. J., 2001. A new method for non-parametric multivariate analysis of variance. Austral Ecology 26: 32-46.

Arroyo, N. L., M. Maldonado, R. Pérez-Portela \& J. Benito, 2004. Distribution patterns of meiofauna associated with a sublittoral Laminaria bed in the Cantabrian Sea (northeastern Atlantic). Marine Biology 144: 231-242.

Balsamo, M., G. Albertelli, V. U. Ceccherelli, R. Coccioni, M. A. Colangelo, M. Curini-Galletti, R. Danovaro, R. D’Addabbo, C. De Leonardis, M. Fabiano, F. Frontalini, M. Gallo, C. Gambi, L. Guidi, M. Moreno, A. Pusceddu, R. Sandulli, F. Semprucci, M. A. Todaro \& P. Tongiorgi, 2010. Meiofauna of the Adriatic Sea: present knowledge and future perspectives. Chemistry and Ecology 26: 45-63.

Beer, T., 1997. Environmental Oceanography. CRC Press, Boca Raton: 402.

Benedetti-Cecchi, L., F. Pannacciulli, F. Bulleri, P. S. Moschella, L. Airoldi, G. Relini \& F. Cinelli, 2001. Predicting the consequences of anthropogenic disturbance: large-scale effects of loss of canopy algae on rocky shores. Marine Ecology Progress Series 214: 137-150.

Bianchelli, S., C. Gambi, D. Zeppilli \& R. Danovaro, 2010. Metazoan meiofauna in deep-sea canyons and adjacent open slopes: a large-scale comparison with focus on the rare taxa. Deep Sea Research Part I: Oceanographic Research Papers 57(3): 420-433.

Bianchelli, S., A. Pusceddu, S. Canese, S. Greco \& R. Danovaro, 2013. High meiofaunal and nematodes diversity around mesophotic coral oases in the Mediterranean Sea. PLoS ONE 8(6): e66553.

Burrows, M. T., R. Harvey \& L. Robb, 2008. Wave exposure indices from digital coastlines and the prediction of rocky shore community structure. Marine Ecology Progress Series 353: 1-12.

Brierley, A. S. \& M. J. Kingsford, 2009. Impacts of climate change on marine organisms and ecosystems. Current Biology 19: 602-614.

Bulleri, F., L. Benedetti-Cecchi, S. Acunto, F. Cinelli \& S. J. Hawkins, 2002. The influence of canopy algae 0 on vertical patterns of distribution of low-shore assemblages on rocky coasts in the northwest Mediterranean. Journal of Experimental Marine Biology and Ecology 267: 89-106.

Carugati, L., C. Corinaldesi, A. Dell'Anno \& R. Danovaro, 2015. Metagenetic tools for the census of marine meiofaunal biodiversity: an overview. Marine Genomics 24: $11-20$.

Chatterji, A., Z. A. Ansari, J. K. Mishra \& A. H. Parulekar, 1995. Seasonality in meiofaunal distribution on a tropical beach at Balramgari, northeast coast of India. Indian Journal of Marine Science 24: 49-55.
Clarke, K. R. \& R. N. Gorley, 2006. PRIMER v6: User Manual/ Tutorial. PRIMER-E, Plymouth.

Cole, V. J., 2010. Alteration of the configuration of bioengineers affects associated taxa. Marine Ecology Progress Series 416: 127-136.

Coll, M., C. Piroddi, J. Steenbeek, K. Kaschner, F. Ben Rais Lasram, J. Aguzzi, E. Ballesteros, C. N. Bianchi, J. Corbera, T. Dailianis, R. Danovaro, M. Estrada, C. Froglia, B. S. Galil, J. M. Gasol, R. Gertwagen, J. Gil, F. Guilhaumon, K. Kesner-Reyes, M. S. Kitsos, A. Koukouras, N. Lampadariou, E. Laxamana, C. M. López-Fé de la Cuadra, H. K. Lotze, D. Martin, D. Mouillot, D. Oro, S. Raicevich, J. Rius-Barile, J. I. Saiz-Salinas, C. San Vicente, S. Somot, J. Templado, X. Turon, D. Vafidis, R. Villanueva \& E. Voultsiadou, 2010. The biodiversity of the Mediterranean Sea: estimates, patterns, and threats. PLoS ONE 5(8): e11842.

Coull, B. C., 1999. Role of meiofauna in estuarine soft-bottom habitats. Australian Journal of Ecology 24: 327-343.

Covazzi-Harriague, A. \& G. Albertelli, 2007. Environmental factors controlling macrofaunal assemblages on six microtidal beaches of the Ligurian Sea (NW Mediterranean). Estuarine, Coastal and Shelf Science 73(1): 8-16.

Covazzi-Harriague, A., C. Misic, I. Valentini, E. Polidori, G. Albertelli \& A. Pusceddu, 2013. Meio- and macrofauna communities in three sandy beaches of the northern Adriatic Sea protected by artificial reefs. Chemistry and Ecology 29(2): 181-195.

Crain, C. M., B. S. Halpern, M. W. Beck \& C. V. Kappel, 2009. Understanding and managing human threats to the coastal marine environment. Annals of the New York Academy of Sciences 1162(1): 39-62.

Crowe, T. P., M. Cusson, F. Bulleri, D. Davoult, F. Arenas, R. Aspden, L. Benedetti-Cecchi, S. Bevilacqua, I. Davidson, E. Defew, S. Fraschetti, C. Golléty, J. N. Griffin, K. Herkül, J. Kotta, A. Migné, M. Molis, S. K. Nicol, L. M.-L. J. Noël, I. S. Pinto, N. Valdivia, S. Vaselli \& S. R. Jenkins, 2013. Large-scale variation in combined impacts of canopy loss and disturbance on community structure and ecosystem functioning. PLoS ONE 8(6): e66238.

Curini-Galletti, M., T. Artois, V. Delogu, W. H. De Smet, D. Fontaneto, U. Jondelius, F. Leasi, A. Martìnez, I. MeyerWachsmuth, K. S. Nilsson, P. Tongiorgi, K. Worsaae \& M. A. Todaro, 2012. Patterns of diversity in soft-bodied meiofauna: dispersal ability and body size matter. PLoS ONE 7(3): e33801.

Danovaro, R., 2010. Methods for the Study of Deep-Sea Sediments, Their Functioning and Biodiversity. CRC Press, Boca Raton.

Danovaro, R. \& S. Fraschetti, 2002. Meiofaunal vertical zonation on rocky-bottoms: comparison with soft-bottom meiofauna. Marine Ecology Progress Series 230: 159-169.

Danovaro, R., M. Scopa, C. Gambi \& S. Fraschetti, 2007. Trophic importance of subtidal metazoan meiofauna: evidence from in situ exclusion experiments on soft and rocky substrates. Marine Biology 152: 339-350.

Danovaro, R., C. Gambi, A. Dell'Anno, C. Corinaldesi, S. Fraschetti, A. Vanreusel, M. Vincs \& A. J. Gooday, 2008. Exponential decline of deep-sea ecosystem functioning linked to benthic biodiversity loss. Current Biology 18(1): $1-8$. 
Defeo, O. \& A. McLachlan, 2013. Global patterns in sandy beach macrofauna: species richness, abundance, biomass and body size. Geomorphology 199: 106-114.

De Zio, S. \& P. Grimaldi, 1966. Ecological aspects of Tardigrada distribution in South Adriatic beaches. Veröff. Institute Meeresforsch. Bremerhaven 2: 87-94.

Dittmann, S., 1990. Mussel beds - amensalism or amelioration for intertidal fauna? Helgoländer Meeresuntersuchungen 44(3): 335.

Du, Y., K. Xu, A. Warren, Y. Lei \& R. Dai, 2012. Benthic ciliate and meiofaunal communities in two contrasting habitats of an intertidal estuarine wetland. Journal of Sea Research 70: 50-63.

Frame, K., G. Hunt \& K. Roy, 2007. Intertidal meiofaunal biodiversity with respect to different algal habitats: a test using phytal ostracodes from Southern California. Hydrobiologia 586: 331-342.

Gartner, A., F. Tuya, P. S. Lavery \& K. McMahon, 2013. Habitat preferences of macroinvertebrate fauna among seagrasses with varying structural forms. Journal of Experimental Marine Biology and Ecology 439: 143-151.

Gaston, K. J., 2000. Global patterns in biodiversity. Nature 405(6783): 220-227.

Gheskiere, T., M. Vincx, B. Urban-Malinga, C. Rossano, F. Scapini \& S. Degraer, 2005. Nematodes from wave-dominated sandy beaches: diversity, zonation patterns and testing of the isocommunities concept. Estuarine Coastal Shelf Science 62: 365-375.

Gibbons, M. J., 1988a. The impact of sediment accumulations, relative habitat complexity and elevation on rocky shore meiofauna. Journal of Experimental Marine Biology and Ecology 122: 225-241.

Gibbons, M. J., 1988b. The impact of wave exposure on the meiofauna of Gelidium pristoides (Turner) Kuetzing (Gelidiales: Rhodophyta). Estuarine Coastal Shelf Science 27: 581-593.

Giere, O., 2009. Meiobenthology. The Microscopic Motile Fauna of Aquatic Sediments, 2nd ed. Springer, Berlin.

Gobin, J. F. \& R. M. Warwick, 2006. Geographical variation in species diversity: a comparison of marine polychaetes and nematodes. Journal of Experimental Marine Biology and Ecology 330(1): 234-244.

Heip, C., M. Vincx \& G. Vranken, 1985. The ecology of marine nematodes. Oceanography and Marine Biology 23: 399-489.

Helmuth, B., 1998. Intertidal mussel microclimates: predicting the body temperature of a sessile invertebrate. Ecological Monographs 68: 51-74.

Helmuth, B., 1999. Thermal biology of rocky intertidal mussels: quantifying body temperatures using climatological data. Ecology 80(1): 15-34.

Helmuth, B., L. Yamane, K. J. Mach, S. Chhotray, P. Levin \& S. Woodin, 2008. All climate change is local: understanding and predicting the effects of climate change from an organism's point of view. Stanford Journal of Law, Science \& Policy 2: 18-35.

Helmuth, B., E. Carrington \& J. G. Kingsolver, 2005. Biophysics, physiological ecology, and climate change: does mechanism matter? Annual Review of Physiology 67: 177-201.
Hulings, N. C. \& J. S. Gray, 1976. Physical factors controlling abundance of meiofauna on tidal and atidal beaches. Marine Biology 34: 77-83.

Ingole, B. S. \& A. H. Parulekar, 1998. Role of salinity in structuring the intertidal meiofauna of a tropical estuarine beach: field evidence. Indian Journal of Marine Sciences 27: 356-361.

Jansson, B. O., 1968. Quantitative and experimental studies of the interstitial fauna in four Swedish sandy beaches. Ophelia 5: 1-71.

Kearney, M., S. J. Simpson, D. Raubenheimer \& B. Helmuth, 2010. Modelling the ecological niche from functional traits. Philosophical Transitional Royal Society B 365: 3469-3483.

Kostylev, V. E., J. Erlandsson, M. J. Ming \& G. A. Williams, 2005. The relative importance of habitat complexity and surface area in assessing biodiversity: fractal application on rocky shores. Ecological Complexity 2: 272-286.

Kotwicki, L., M. Szymelfenig, M. De Troch, B. Urban-Malinga, T. Gheskiere \& J. M. Weslawski, 2005. Latitudinal biodiversity patterns of meiofauna from sandy littoral beaches. Biodiversity and Conservation 14: 461-474.

Kotwicki, L., A. Deidun, K. Grzelak \& K. Gianni, 2014. A preliminary comparative assessment of the meiofaunal communities of Maltese pocket sandy beaches. Estuarine, Coastal and Shelf Science 150: 111-119.

Kroeker, K. J., E. Sanford, J. M. Rose, C. A. Blanchette, F. Chan, F. P. Chavez, B. Gaylord, B. Helmuth, T. M. Hill, G. E. Hofmann, M. A. McManus, B. A. Menge, K. J. Nielsen, P. T. Raimondi, A. D. Russell \& L. Washburn, 2016. Interacting environmental mosaics drive geographic variation in mussel performance and predation vulnerability. Ecology Letters 19: 771-779.

Lima, G. M. \& J. A. Pechenik, 1985. The influence of temperature on growth rate and length of larval life of the gastropod, Crepidula plana Say. Journal of Experimental Marine Biology and Ecology 90(1): 55-71.

Logan, D., K. A. Townsend, K. Townsend \& I. R. Tibbetts, 2008. Meiofauna sediment relations in leeward slope turf algae of Heron Island reef. Hydrobiologia 610: 269-276.

Lorenzen, C. \& J. Jeffrey, 1980. Determination of chlorophyll in seawater. Unesco Technical Papers in Marine Sciences 35(1): 1-20.

McArdle, B. H. \& M. J. Anderson, 2001. Fitting multivariate models to community data: a comment on distance-based redundancy analysis. Ecology 82: 290-297.

Menge, B. A., C. Blanchette, P. Raimondi, T. Freidenburg, S. Gaines, J. Lubchenco, D. Lohse, G. Hudson, M. Foley \& J. Pamplin, 2004. Species interaction strength: testing model predictions along an upwelling gradient. Ecological Monographs 74(4): 663-684.

Norkko, A., J. E. Hewitt, S. F. Thrush \& G. A. Funnell, 2001. Benthic-pelagic coupling and suspension-feeding bivalves: linking site-specific sediment flux and biodeposition to benthic community structure. Limnology and Oceanography 46: 2067-2072.

Norling, P. \& N. Kautsky, 2007. Structural and functional effects of Mytilus edulis on diversity of associated species and ecosystem functioning. Marine Ecology Progress Series 351: 163-175. 
Norling, P. \& N. Kautsky, 2008. Patches of the mussel Mytilus sp. are islands of high biodiversity in subtidal sediment habitats in the Baltic Sea. Aquatic Biology 4: 75-87.

Papageorgiou, N., M. Moreno, V. Marin, S. Baiardo, C. Arvanitidis, M. Fabiano \& A. Eleftheriou, 2007. Interrelationships of bacteria, meiofauna and macrofauna in a Mediterranean sedimentary beach (Maremma Park, NW Italy). Helgoland Marine Research 61: 31-42.

Pusceddu, A., A. Dell' Anno, E. Manini, M. Fabiano, G. Sarà \& R. Danovaro, 2003. Enzymatically hydrolysable protein and carbohydrate sedimentary pools as indicators of the trophic state of 'detritus sink' systems: a case study in a Mediterranean coastal lagoon. Estuaries 26: 641-650.

Pusceddu, A., S. Bianchelli, M. Canals, X. Durrieu De Madron, S. Heussner, V. Lykousis, H. de Stigter, F. Trincardi \& R. Danovaro, 2010. Organic matter in sediments of canyons and open slopes along European continental margins. Deep-Sea Research I 57: 441-457.

Pusceddu, A., S. Bianchelli, C. Gambi \& R. Danovaro, 2011. Assessment of benthic trophic status of marine coastal ecosystems: significance of meiofaunal rare taxa. Estuarine, Coastal and Shelf Science 93(4): 420-430.

Radziejewska, T., C. Fenske, B. Wawrzyniak-Wydrowska, P. Riel, A. Woźniczka \& P. Gruszka, 2009. The zebra mussel (Dreissena polymorpha) and the benthic community in a coastal Baltic lagoon another example of enhancement? Marine Ecology 30: 138-150.

Reise, K., 2002. Sediment mediated species interactions in coastal waters. Journal of Sea Research 48(2): 127-141.

Rodríguez, J. G., M. Lastra \& J. López, 2003. Meiofauna distribution along a gradient of sandy beaches in northern Spain. Estuarine, Coastal and Shelf Science 58: 63-69.

Rohde, K., 1992. Latitudinal gradients in species diversity: the search for the primary cause. Oikos 65: 514-527.

Sandulli, R., C. De Leonardis \& J. Vanaverbeke, 2010. Meiobenthic communities in the shallow subtidal of three Italian marine protected areas. Italian Journal of Zoology 77(2): 186-196.

Sarà, G., M. Kearney \& B. Helmuth, 2011. Combining heattransfer and energy budget models to predict thermal stress in Mediterranean intertidal mussels. Chemistry and Ecology 27: 135-145.

Sarà, G., V. Palmeri, A. Rinaldi, V. Montalto \& B. Helmuth, 2013. Predicting biological invasions in marine habitats through eco-physiological mechanistic models: a case study with the bivalve Brachidontes pharaonis. Diversity and Distributions 19(10): 1235-1247.
Sarà, G., M. Milanese, I. Prusina, A. Sara, D. L. Angel, B. Glamuzina, T. Nitzan, S. Freeman, A. Rinaldi, V. Palmeri, V. Montalto, M. Lo Martire, P. Gianguzza, V. Arizza, S. Lo Brutto, M. De Pirro, B. Helmuth, J. Murray, S. De Cantis \& G. A. Williams, 2014. The impact of climate change on Mediterranean intertidal communities: losses in coastal ecosystem integrity and services. Regional environmental change 14(1): 5-17.

Semprucci, F., P. Colantoni, C. Sbrocca, G. Baldelli, M. Rocchi \& M. Balsamo, 2011. Meiofauna in sandy back-reef platforms differently exposed to the monsoons in the Maldives (Indian Ocean). Journal of Marine Systems 87(3): 208-215.

Semprucci, F., F. Frontalini, C. Sbrocca, E. A. Du Châtelet, V. Bout-Roumazeilles, R. Coccioni \& M. Balsamo, 2015. Meiobenthos and free-living nematodes as tools for biomonitoring environments affected by riverine impact. Environmental Monitoring and Assessment 187(5): 251.

Semprucci, F., C. Sbrocca, G. Baldelli, M. Tramontana \& M. Balsamo, 2016. Is meiofauna a good bioindicator of artificial reef impact? Marine Biodiversity. doi:10.1007/ s12526-016-0484-3.

Soltwedel, T., 2000. Metazoan meiobenthos along continental margins: a review. Progress in Oceanography 46: 59-84.

Urban-Malinga, B., T. Gheskiere, S. Degraer, S. Derycke, K. W. Opalinski \& T. Moens, 2008. Gradients in biodiversity and macroalgal wrack decomposition rate across a macrotidal, ultradissipative sandy beach. Marine Biology 155: 79-90.

Wieser, W. \& F. Shiemer, 1977. The ecophysiology of some marine nematodes from Bermuda: seasonal aspect. Journal of Experimental Marine Biology and Ecology 26: 97-106.

Yasuhara, M., G. Hunt, G. Dijken, K. R. Arrigo, T. M. Cronin \& J. E. Wollenburg, 2012. Patterns and controlling factors of species diversity in the Arctic Ocean. Journal of Biogeography 39(11): 2081-2088.

Zeppilli, D., M. Canals \& R. Danovaro, 2012. Pockmarks enhance deep-sea benthic biodiversity: a case study in the western Mediterranean Sea. Diversity and Distributions 18(8): 832-846.

Zeppilli, D., L. Bongiorni, A. Cattaneo, R. Danovaro \& R. S. Santos, 2013. Meiofauna assemblages of the Condor Seamount (North-East Atlantic Ocean) and adjacent deepsea sediments. Deep Sea Research Part II: Topical Studies in Oceanography 98: 87-100. 